\title{
$\mathrm{NiO}$ の初期焼結における雾囲気酸素の影響
}

\author{
小松和蔵・守吉佑介・仲
}

榛

(東京工業大学 工学部)

\section{The Effect of Oxygen Pressure on Initial Sintering of Nickel Oxide}

By

Wazo KOMATSU, Yusuke MORIYOSHI, and Itaru NAKA

(Faculty of Engineering, Tokyo Institute of Technology)

\begin{abstract}
The effect of oxygen pressure $\left(4 \times 10^{-6}\right.$ to 140 torr $)$ on initial sintering of nickel oxide has been investigated by measuring the isothermal shrinkage and the electical conductivity of compacts at $850^{\circ} \mathrm{C}$. The data were analyzed by using the kinetic equation of initial combined sintering for volume and surface diffusion. The shrinkage data indicated that the term of volume diffusion increased as $p_{\mathrm{O}_{2}}{ }^{1 / 4.8}$ in oxygen atmosphere $\left(p_{\mathrm{O}_{2}}>4 \times 10^{-3}\right.$ torr) and that of surface diffusion was proportional to $p_{\mathrm{O}_{2}}{ }^{1 / 4.1}$ (in the pressure range of $\mathrm{O}_{2}$ from $4 \times 10^{-6}$ to 140 torr). From the pressure dependence of sinterability and conductivity, it was presumed that the sintering of nickel oxide was controlled by the diffusional transfer of trivalent nickel ions $\left(\mathrm{Ni}^{3+}\right)$ partially associated with cation vacancies.
\end{abstract}

[Received September 25, 1973]

\section{1. 緒言}

$\mathrm{NiO}$ の焼結に関しては, 従来, 飯田ら ${ }^{1)}$ の研究と Brown $^{2)}$ の研究とが知られている.飯田らの研究は, 焼 結の中期および後期に着目したものであって, 焼結にお ける粒成長, 電気伝導度の変化, 雾囲気の影響, 不純物 の影響などを系統的に調べている・また，Brown は葆 酸ニッケルを分解して, $\mathrm{NiO}$ 試料をつくる際の分解温 度と焼結性との関係を調べている。

一方，著者らは初期焼結の観点から焼結現象をとら え, $\mathrm{NiO}$ の焼結に抢ける不純物の影響を研究した ${ }^{3}$. そ の結果, $\mathrm{NiO}$ の焼結は, イオン半径の小さい 3 価の二 ッケルイオン（正孔）の拡散により律速されることを推 定した。

この推論を別の立場から確かめるため, 正孔濃度が雾 囲気酸素圧と平衡関係にあることに着目して, 広範囲に 雾囲気酸素圧を変えて, 焼結性と酸素分圧との関係につ いて研究した. $\mathrm{NiO}$ は陽イオン空孔をつくる典型的な $\mathrm{P}$ 型半導体酸化物でガス中の酸素と (1) 式のような平衡関 係がある ${ }^{4)}$.

$$
\frac{1}{2} \mathrm{O}_{2}(\mathrm{~g}) \rightleftarrows \mathrm{NiO}(l)+|\mathrm{Ni}| "+2 \oplus
$$

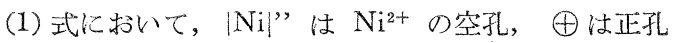
$\left(\mathrm{Ni}^{3+}\right)$ である。|Ni|" 㧍よび円の濃度を, $x_{\left.|\mathrm{N}|\right|^{\prime}}, x_{\oplus}$ と して, (1) 式に質量作用の法則を適用し, さらに,
$2 x_{|\mathrm{Ni}|}$ ” $=x_{\oplus}$ を考慮すると (2) 式となる.

$$
x_{\oplus}=\text { const } \cdot p_{\mathrm{O}_{2}}{ }^{1 / 6} \text {. }
$$

正孔，つまり $\mathrm{Ni}^{3+}$ イオンの拡散が焼結性を支配する なら, 正孔濃度と酸素圧 $\left(p_{\mathrm{O}_{2}}\right)$ との間には (2) 式の関 係があるから， $\mathrm{NiO}$ の燒結性は酸素圧の $1 / 6$ 乗に比例す ることが推定される。

\section{2. 実験}

市販特級硝酸ニッケル $\mathrm{Ni}\left(\mathrm{NO}_{3}\right)_{2} \cdot 6 \mathrm{H}_{2} \mathrm{O}$ を砂具上の 磁器中で低温予備分解して, 黒色の $\mathrm{NiO}$ を調製し, こ れを $600^{\circ} \mathrm{C}, 15$ 時間空気中で処理して, さらに $650^{\circ} \mathrm{C}$, 3 時間空気中で加熱して試料とした. 電子顕微鏡観察に よれば, 粒径は $0.2 \mu$ 程度のものであった。

錠剤の作製には通常のプレスを用い，試料約 $800 \mathrm{mg}$ を $1 \mathrm{t} / \mathrm{cm}^{2}$ の荷重を加えて, 直径 $10 \mathrm{~mm}$, 厚さ $4 \mathrm{~mm}$ 程 度の錠剤に成形した。焼結前の錠剤の密度は理論密度の ほぼ $50 \%$ であった。

収縮率の測定には, 差動偏位測定器を用いて行なっ だ、焼結を行なう前に試料の吸着水および吸着ガスの 除去のため, 常温において $10^{-6}$ torr で 30 分間排気処理 を行ない, その後, 所定の酸素ガスを導入した.

焼結には，たて型の電気炉を用い，先ず電気炉を所定 の燒結温度に調節しておき，試料をセットした反応管を 所定温度より約 $300^{\circ} \mathrm{C}$ 低い位置にして, 電気炉を 10 分 


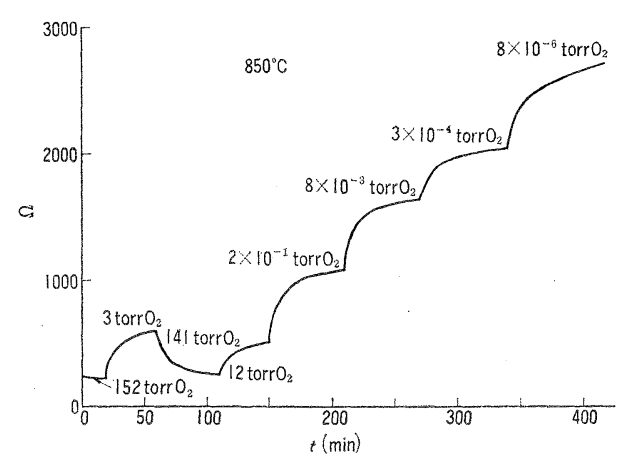

Fig. 1. Responsibility of resistance of $\mathrm{NiO}$ compacts to oxygen pressure.

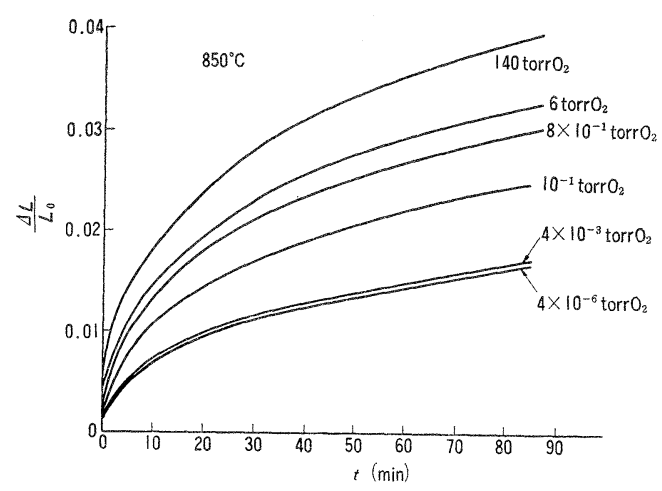

Fig. 2. Linear plots of shrinkage for sintering of $\mathrm{NiO}$ compacts at various oxygen pressure.

間保持してから, 試料が所定温度の位置にくるように電 気炉を移動させて，焼結を行なった，真空度の測定に は，回転マクレオード真空計㧍よび水銀マノメーターを 用いた。低圧実験の場合，水銀蒸気を除去するため液体 窒素トラップを用いた。

\section{3. 実験結果および考察}

正孔の濃度に関する情報は, 電気伝導度を測定するこ とによってえられるから，雾囲気酸素圧を変えた場合の 電気伝導度の時間変化を測定して, $\mathrm{NiO}$ 試料と雾囲気酸 素圧との平衡関係を調べた. 図-1 には $850^{\circ} \mathrm{C}$ で測定し た抵抗值と時間との関係を示した．図からわかるよう に, 雾囲気酸素圧を変えると, 10分ぐらいまでに抵抗值 が急激に変化し，その後，ゆるやかに変化していくこと がわかる、そして短時間のうちに，抵抗值が一定にはな らず，非平衡の状態が続く、㧍そらく, 試料の表面は雾 囲気酸素と速やかに平衡に達するが, 内部の平衡到達に はかなりの時間がかかるためと推定される。図-2 に示 すように，実際の焼結では30分ぐらいまでの間に著しく 焼結が進行寸ることから, 雾国気酸素と $\mathrm{NiO}$ 試料とは 若干非平衡のまをで焼結が進行すると推論される。電気 伝導度の時間変化恃, 初めに大きく, 10分程度で比較的

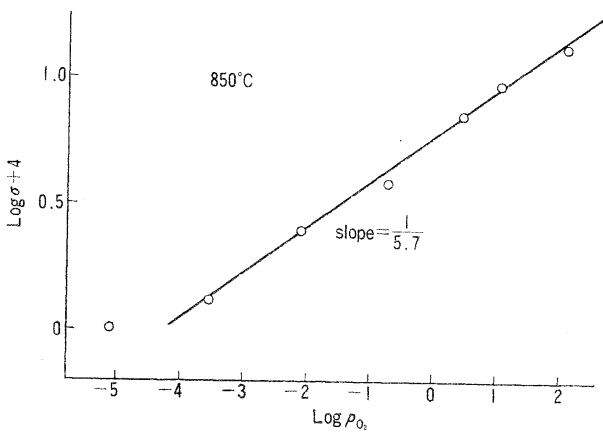

Fig. 3. Effect of oxygen pressure on conductivity of $\mathrm{NiO}$.

おちつき, その後, 焼結実験の時間内では, それほど大 きく変化しないので, 電気伝導度の測定は所定の酸素圧 に調整してから10分後に行なった。

図-3 には $850^{\circ} \mathrm{C}$ で測定した見掛けの電気伝導度 $\sigma$ と 雾囲気酸素圧 $p_{\mathrm{O}_{2}}$ との両対数プロットを示した. デー 夕は良い直線であらわされ，その勾配を求めると $1 / 5.7$ となり, 正孔濃度の酸素圧依存性がほぼ (2) 式に従うこ とがわかる. Baumbach ら ${ }^{4)}$ は $900^{\circ} \mathrm{C}$ および $1000^{\circ} \mathrm{C} に$ おりる $\mathrm{NiO}$ の比伝導度は酸素圧の $1 / 4.5$ 乗に比例する と報告している。 また, Wagner $ら^{6 /}$ および Fisher ら は $\mathrm{NiO}$ と同様の結晶構造をもち, かつ同じ久陥構造を もつ $\mathrm{CoO}$ の電気伝導度は, 酸素圧の $1 / 4$ 乗ないしは $1 / 5$ 乗に比例すると報告している。最近, 市村ら ${ }^{8)}$ は $\mathrm{CoO}$ の電気伝導度を $400^{\circ} \sim 750^{\circ} \mathrm{C}$ の範囲で測定し, 酸素圧の $1 / 6$ 乗に比例することを報告している.

雰囲気酸素圧をいろいろに湾えた場合の $850^{\circ} \mathrm{C}$ に抒 ける收縮率と時間との関係は 図-2 に示すように, いず れの場合も曲線の形は似ており, どちらも酸素圧が高く なるほど収縮率が大きく焼結性が良くなっていくことが わかる。

焼結における酸素圧依存性を定量的に検討するために は，収縮率のデータがどのような速度式でよくあらわさ れるかを十分検討する必要があり，特に粒子が $1 \mu$ 以下 のようなとき, 複数の機構によって, 焼結が進行すると 考えられるので, 複合焼結の速度式を用いる必要がある と思われる。例えば, Tikkanen ${ }^{9}$ はニッケルの錠剤焼結 に㧍いて, 粒子が小さくなると複数の機構がかさなって おこり, そのため, えら机る見掛けの活性化エネルギー が単一機構の場合にくらべて変ることを指摘している. また, Rockland ${ }^{10)}$ は $1 \mu$ 以下の粒子では体積拡散に対 する表面拡散の寄与割合がきわめて大きくなることを銅 球の焼結で定量的に示している. 本研究で用いた $\mathrm{NiO}$ の粒径は $0.2 \mu$ 程度であり, 複数の機構がかさなってお こることが十分考えら机る。气二で, 本報では，体精搪

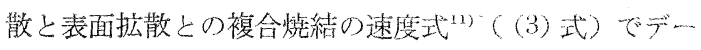
夕を整理した。 


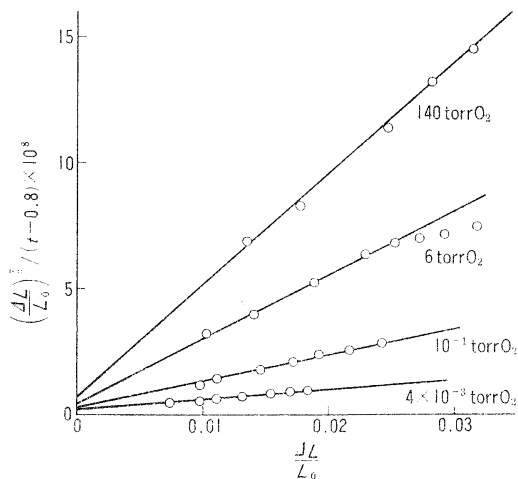

Fig. 4. Correlation between $\left(d L / I_{0}\right)^{7 / 2} /(t-0.8)$ and $J L / L_{0}$ for $\mathrm{NiO}$ compacts at various oxygen pressure.

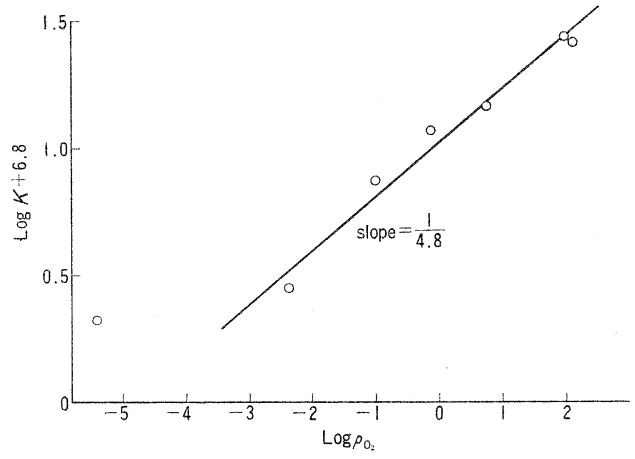

Fig. 5. Effect of oxygen pressure on volume diffusion term of $\mathrm{NiO}$ compacts.

$$
\frac{\left(\frac{\Delta L}{L_{0}}\right)^{7 / 2}}{t-d t}=K \frac{\Delta L}{L_{0}}+H
$$

ここで $K=7 \gamma \Omega D_{v} / 4 m^{5} a^{3} k T, H=7 \delta \gamma \Omega D_{s} / 4 m^{7} a^{7} k T$ で, $r$ : 表面エネルギー, $\Omega$ : 格子点体積, $D_{v}$ : 体穦拡 散係数, $m:$ パラメーター, $a:$ 粒子の半径, $k:$ ボルツ マン定数, $T$ : 絶対温度, $\delta$ : 表面扡散層の厚さ, $D_{s}$ : 表面拡散係数である.

図-2 の収縮率のデータを用いた（3）式のプロットを 図-4に示した、いずれの場合も収縮率が $2.5 \%$ まで良 、直線であらわされ，雾囲気酸素圧が低くなるほど，収 縮率が小さくなり，焼結性が悪くなることがわかる.

(3)式からわかるよらに, これらの直線の勾配 $(K)$ は体 積拡散係数を含み, 切片 $(H)$ は表面拡散係数を含んで いる、そして，一定温度では～$K$ および $H$ の中に含ま れている諸因子のうち, 拡散係数の中に含まれている久 宿濃度の項のみが, 雾囲気酸素圧に依存すると考えられ るから， $K$ 抢よび $H$ をそれぞれ雲团気酸素压 $p_{\mathrm{O}_{2}}$ よ 両詨数プロットすることによって，体積拡散执よび表面 拡散の酸素压依存性を調べることができる。

図-40每配加らえられる $K \longleftarrow p_{2}$ との両対数 ッ卜を図-5 に示した。 $4 \times 10^{-3}$ torr $\mathrm{O}_{2}$ 以下では, 酸素 压依存性がほとんどなく，それより高い酸素压になると

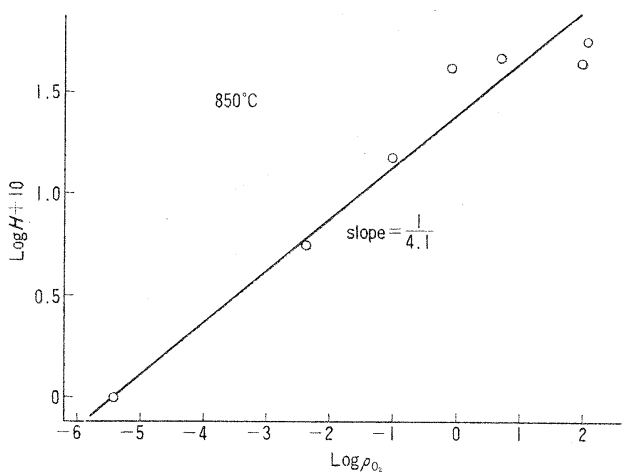

Fig. 6. Effect of oxygen pressure on surface diffusion term of $\mathrm{NiO}$ compacts.

依存性があることがわかる。この酸素压に依存する部分 の勾配を求めると $1 / 4.8$ となり，Kが酸素圧の $1 / 4.8$ 乗 に比例する.また，図 -4 の直線を $\Delta L / L_{0}=0$ に外挿し てえられる切片 $(H)$ と酸素圧との両対数プロットを, 図-6に示した。図からわかるよらに，一様に酸素圧依 存性があり，その勾配は $1 / 4.1$ となる.これらの酸素圧 依存性の結果から，焼結の拉散過程について 推論する と, 実際の拡散は正孔が単一で移動するのではなく，正 孔が $\mathrm{Ni}^{2+}$ の空孔をつかって，つまり会合するようにし て，拡散にあずかると考えられる。そこで，(2)式をえ たのと同様にして, $\mathrm{Ni}^{2+}$ の空孔濃度 $x_{|\mathrm{N}|}$ ”と正孔の濃度 $x_{\oplus}$ について, 会合している場合の酸素圧依存性を考え てみると(4)式のようになり，この結果は酸素圧の $1 / 4$ 乗 に比例し，実験結果と比較的よく一致する。

$$
x_{[|\mathrm{Ni}|}{ }^{\prime \prime+\oplus]}=\mathrm{const} \cdot p_{\mathrm{O}_{2}}{ }^{1 / 4}
$$

体積扩散の酸素圧依存性が $p_{\mathrm{O}_{2}}$ の $1 / 4.8$ 采に比例して， 表面拡散の場合の $1 / 4.1$ 乗と若干異なるのは，先に述心゙ たごとく，雾囲気酸素と試料との平衡が完全に内部まで 到達していないこと，(2) 式および (4) 式にしたがう正 孔の桩散がかさなっておこること, あるいは, 表面拡散 の方が体積拡散より速いために，雾国気酸素に表面拡散 がより鋭感であることに原因するのか明確でない。

ここでえられた焼結の酸素圧依存性の結果は，焼結の 物質移動が，陽イオンの拡散により支配されることを示 している、しかしながら，酸化物の焼結において，陰陽 両イオンのらち, どちらの拡散過程が焼結を律速するの かが，しばしば問題となるので， $\mathrm{NiO}$ の焼結データ (140 torr $\mathrm{O}_{2}$ 中， $750^{\circ} \sim 900^{\circ} \mathrm{C}$ ) 加ら求められる $\mathrm{K}$ 抢よ び $H$ の颠に $r=10^{3} \mathrm{erg} / \mathrm{cm}^{2}, \Omega=1.6 \times 10^{-23} \mathrm{~cm}^{3}$ および $\delta=10^{-8} \mathrm{~cm}$ を代入してえた拡散倸数と $\mathrm{NiO}$ 中の二ッケ ルイオンおよび酸素イオンの自己拡散係数とを調ベてみ た（図-7). 図からわかるように，焼結データからえら れる表面拡散倸数は 1 番大きくなり、去た，体積拡散保

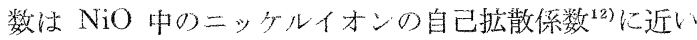
值しなる。それに対して $\mathrm{NiO}$ 中の酸素イオンの自己搪 


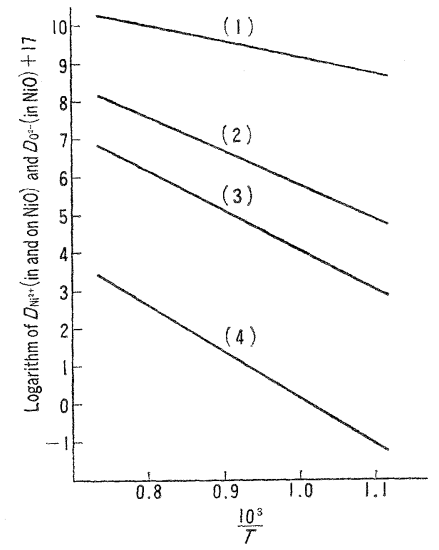

Fig. 7. Comparison of diffusion coefficients obtained from tracer diffusion and sintering data. Curves (1) and (2); $D_{s}$ and $D_{v}\left(\mathrm{Ni}^{2+}\right.$ ion $)$ obtained in this work, curve (3); $D_{v}\left(\mathrm{Ni}^{2+}\right.$ ion) by Shim and Moore, curve (4); $D_{v}\left(\mathrm{O}^{2-}\right.$ ion) by O'Keeffe and Moore.

散係数 ${ }^{139}$ はニッケルイオンのそれより $10^{-5}$ 程度小さい.

これは $\mathrm{NiO}$ の焼結性が遅い方の酸素イオンの拡散に よるのではなく、ニッケルイオンの拡散により支配され ることを示している。

それでは何故, 遅い酸素イオンの拡散が焼結性を律速 しないか，といらことであるが, Gupta ら ${ }^{14}$ は中期およ び後期における $\mathrm{ZnO}$ の粒成長と緻密化の研究において, 酸素イオンは粒界を著しく速く動くために, 酸素イオン でなく，陽イオンの抾散が焼結を律速すると報告してい る.また, Paladino ら ${ }^{15)}$ は同様の考えから $\mathrm{Al}_{2} \mathrm{O}_{3}$ の焼 結は酸素イオンの拡散ではなく, 陽イオンの拡散により 律速されると報告している. 最近では Shackelfordら ${ }^{16)}$ は $\mathrm{Al}_{2} \mathrm{O}_{3}$ の thermal grooving の研究に执いて, 酸素 イオンの拡散は律速にならないと報告している。一方， 加成的固相反応に拉いて, 遅い方の酸素イオンの拡散が 律速でないことを説明するために，酸素イオンは， $\mathrm{O}^{2-}$ $\rightarrow 1 / 2 \mathrm{O}_{2}(\mathrm{~g})+2 \ominus$ となり, 酸素は気相を通り移動する ことが提唱されている゙ $\mathrm{Co}_{2} \mathrm{TiO}_{4}$ および $\mathrm{CoCr}_{2} \mathrm{O}_{4}$ の生成反応において, 窒素雲 用気中より酸素雾囲気中の方がはるかに反応速度が速い ことを認めており，市村ら ${ }^{8}$ も $\mathrm{CoAl}_{2} \mathrm{O}_{4}$ の生成反応に同 様の結果をえている．これらの報告をもとにして考えれ ば， $\mathrm{NiO}$ の焼結においても，酸素イオンは粒界を非常 に速く動くか，あるいは，ガス中を搪散して動くことが 十分考えられる.

そこで, $\mathrm{NiO} の$ 焼結がどのように進行するかを考えて みると次のよらになる。 (i) 正孔 $\left(\mathrm{Ni}^{3+}\right)$ が $\mathrm{Ni}^{2+}$ の空 孔と一部会合しのつ表四拡散および体積搪散とによ。 て, 粒子間市ック部分に拡散する。(ii) 酸素は粒界拡散
か, ガス中の移動かによって，ネック部分でニッケルイ オンと格子形成にあずかり，ネック部分の成長がおこる と推定される.そして， $\mathrm{NiO}$ の焼結は，(i)，(ii）の過 程のらち，(i) の正孔の拡散によって律速されると考え られる。

体積桩散の場合に図-5 からわかるように, 酸素圧が $4 \times 10^{-3}$ torr $\mathrm{O}_{2}$ 以下の領域で酸素圧依存性がない。この 理由に関しては現在明確ではなく，この解明のためには もっと低圧側での焼結データを集積する必要があろう.

\section{4. 結論}

$\mathrm{NiO}$ の正孔濃度は雾囲気酸素 $\left(4 \times 10^{-6} \sim 140\right.$ torr $\left.\mathrm{O}_{2}\right)$ との平衡関係から推定されるので, 雾囲気酸素圧をいろ いろに変えた場合の $\mathrm{NiO}$ の初期焼結について研究し, 複合焼結の式を用いてデータの整理を行なった.

その結果, 体積拡散では $4 \times 10^{-3}$ torr $\mathrm{O}_{2}$ よりも高い 酸素圧の下で, $p_{\mathrm{O}_{2}}{ }^{1 / 4.8}$ に, 表面拡散の場合は, 一様に 圧依存性があり, $p_{\mathrm{O}_{2}}{ }^{1 / 4.1}$ に比例することを明らかにし た.これらの結果および電気伝導度の測定結果とから焼 結機構について考察し, $\mathrm{NiO} の$ 焼結は正孔とニッケルイ オンの空孔とが一部会合して，体積拡散および表面拡散 とによって物質移動にあずかるものと推論した。

\section{文献}

1）飯田義男, 尾崎俊郎, 名工試報告 7, 29 (1958).

2) R.A. Brown, J. Am. Ceram. Soc. 48, 627 (1965).

3) 小松和蔵, 宮本美貴夫, 藤田尚志, 守吉佑介, 窯協 76, 407 (1968).

4) H. H.v. Baumbach, C. Wagner, Z. Phys. Chem. B 24, 59 (1934).

5) Y. Moriyoshi, W. Komatsu, J. Am. Ceram. Soc. 53, 671 (1970).

小松和嵗, 守吉佑介, 窵協 80 [1] 31-35 (1972).

6) C. Wagner, E. Koch, Z. Phys. Chem. B 32, 439 (1936).

7) B. Fisher, D.S. Tannhauser, J. Electrochem. 111, 1194 (1964).

8）市村博司, 小松和藏, 未発表.

9) M. Tikkanen, Planseeber. Pulvermet.11, 70 (1963).

10) J.G.R. Rockland, Acta Met. 15, 277 (1967).

11) Y. Moriyoshi, W. Komatsu, Yogyo-Kyokai-Shi 81 [3] 102-07 (1973).

12) M.T. Shim, W.J. Moore, J. Chem. Phys. 26, 802 (1957).

13) M. O'Keeffe, W.J. Moore, J. Phys. Chem. 65, 1436 (1961).

14) T.K. Gupta, R.L. Coble, J. Am. Ceram. Soc. 51, 521 (1968).

15) A.E. Paladino, R.L. Coble, ibid. 46, 134 (1963).

16) J.F. Shackelford, W.D. Scott, ibid. 51, 688 (1968).

17) K. Hauffe, "Reactionen in und an Festen Stoffen", Springer-Verlag, Berlin (1966) s. 821.

18) H. Schmalzried, Z. Phys. Chem. NF 33, 111 (1962). (9/25/1973 受付) 